\title{
13
}

\section{Transnational Actors and Institutionalization of Social Protection in the Global South}

\author{
Armando Barrientos
}

\section{Introduction}

Low- and middle-income countries are engaged in a large expansion of social protection institutions, but especially social assistance. Some comparative research on the growth of social assistance has attributed this expansion to the influence of transnational actors, particularly multilaterals (Peck and Theodore 2015; Yeates 2018). ${ }^{1}$ This chapter challenges this widely held view, for which a review of the findings and approaches of the

\footnotetext{
The chapter benefitted from detailed comments by Carina Schmitt and participants in the workshop on "Building social protection systems in the Global South: different trajectories and the influence of external factors", at SOCIUM Research Centre on Inequality and Social Policy, Bremen University, 7-8 June 2018. Any remaining error is mine alone.
}

${ }^{1}$ This is an abridged list; see the text for further references.

\footnotetext{
A. Barrientos ( $\square)$

Global Development Institute, University of Manchester, Manchester, UK e-mail: Armando.Barrientos@manchester.ac.uk 
current comparative literature fails to find strong support. Addressing this issue is important because it raises fundamental questions about the focus, scope and methods of comparative research on emerging welfare institutions in low- and middle-income countries. Interdependencies, transnational actors included, are likely to have a stronger influence on the shape of welfare institutions in low- and middle-income countries than they did in the development of welfare states in long-standing industrialized countries. The chapter argues that a focus on institutions as opposed to policies, better data and quantitative methods as well as a clearer conceptualization of the role of transnational actors will take us further toward theorizing emerging welfare institutions in low- and middle-income countries.

In low- and middle-income countries, social assistance consists of programs and policies providing budget-financed and rules-based transfers to households and individuals, with the aim of facilitating sustained exit from poverty. ${ }^{2}$ Based on data from the World Bank's ASPIRE database (The Atlas of Social Protection Indicators of Resilience and Equity), the 2015 State of Safety Nets Report stated that social assistance reached 2 billion people in low- and middle-income countries (World Bank 2015). ${ }^{3}$ A regional breakdown from the same data confirms that social assistance is the predominant component of social protection in low- and middle-income countries when measured in terms of range.

This expansion of social assistance has far-reaching implications for emerging welfare institutions. One of these is the likely balance between social insurance and social assistance components within social protection. Expectations that social insurance institutions would come to dominate social protection in low- and middle-income countries, based on the development of similar institutions in Europe and on long-standing International Labour Organization (ILO) advocacy, would need to be heavily discounted. The scope and scale of social assistance institutions in

\footnotetext{
${ }^{2}$ Social assistance is heterogeneous across, and within, national and sub-national contexts (Barrientos 2013).

${ }^{3}$ A global count using the Social Assistance in Low and Middle Income Countries database SALMIC (Barrientos 2018) puts the range of social assistance at below 1 billion. The World Bank measures safety nets, which combine social assistance and emergency and humanitarian assistance. In sub-Saharan Africa and perhaps elsewhere, short-term public works and school feeding programs, arguably emergency assistance, bulk up the World Bank estimates.
} 
low- and middle-income countries belies the residual and compensatory role of social assistance in European countries. A strong focus on social investment, innovations in information tracking of vulnerable population groups, impact evaluations and the emergence of dedicated Ministries of Social Development, all these indicate a distinctive institutional development in low- and middle-income countries.

The expansion of social assistance has coincided with an increased interest in growing interdependencies in policy-making, including social policy (Obinger et al. 2013). It is a fact that economic liberalization, migration and global value chains, among others, work to limit the explanatory power of research focusing exclusively on domestic social protection policy. Comparative research, paying attention to interdependencies, stands a better chance to understand emerging welfare institutions everywhere, but especially in low- and middle-income countries.

Disproportionate attention given to the role of transnational actors in current comparative research on emerging welfare institutions in lowand middle-income countries might turn out to be counterproductive. First, it biases the focus of comparative research toward short-term policies as opposed to long-term institutions, and overwhelmingly on the processes of policy adoption and diffusion. The research question implicit in this approach is "what makes policies move transnationally?" This is in contrast to "what explains the shape of emerging welfare institutions in low- and middle-income countries?" Whereas the former can be answered with little or no engagement with domestic conditions, the latter requires a deeper engagement with domestic politics. Second, distance has encouraged a focus on ideational factors in social policy adoption, especially the ideational flows associated with international organizations (Béland 2016; Béland and Orenstein 2013; Jenson 2010). Third, an excessive focus on the agency of transnational actors diverts attention from discussing appropriate comparative methods, both qualitative and quantitative. ${ }^{4}$

\footnotetext{
${ }^{4}$ Peck and Theodore eloquently describe the problem: "[T]he persistent challenge was to avoid slipping into a form of sampling, as it were, on the dependent variable, and merely affirming some anticipated account of policy hypermobility, as articulated by the most powerful players (many of whom had interests in promoting such narratives). We had to avoid becoming dupes of the policy networks themselves" (Peck and Theodore 2015, Loc254). From my reading, they were not entirely successful.
} 
Some of these shortcomings are acknowledged in the literature. Yeates (2018) discusses current gaps in appropriate tools and approaches. Obinger et al. (2013) undertake a balanced assessment of qualitative and quantitative methods applied to the studying of social policy diffusion and transfers. They note the scarcity of "empirical analysis of the exact conditions and mechanisms of diffusion and transfer" (Obinger et al. 2013, 122).

This chapter argues that disproportionate attention paid to ideational flows from international organizations imposes a reductive perspective which moves us away from theorizing emergent welfare institutions in low- and middle-income countries. This is partly due to deficiencies in the conceptualization of transnational actors and their influences and partly to the challenges faced by comparative methods, data included. In this chapter, alternative conceptualizations of the role of transnational influences are sketched. It makes a case for refocusing comparative research on explaining the shape of emerging institutions in low- and middle-income countries, paying greater attention to the influence of interdependencies on domestic factors and encouraging quantitative comparative methods.

The chapter is organized around three further sections and a conclusion. Section "Comparative Research on Social Assistance" provides a brief review of methods and findings in the scarce comparative literature on the expansion of social assistance in low- and middle-income countries. Section "Social Policy Adoption and Emerging Institutions" discusses two "canonical" examples of transnationally driven social policy diffusion: provident funds and individual retirement accounts. They demonstrate that a focus on transnationally driven policy transfers might not tell us very much about the emerging welfare institutions in low- and middle-income countries. Section "Conceptualizing Transnational Actors" sketches a conceptualization of the role of transnational influences and actors in social policy, distinguishing phenomenological from realist perspectives. A final section presents conclusions. 


\section{Comparative Research on Social Assistance}

This section aims at providing a very brief review of available comparative research on emerging social assistance in low- and middle-income countries. The section focuses solely on multi-country studies and on their methods and key findings. ${ }^{5}$ This literature is scarce and predominantly based on qualitative methods. Its bulk focuses on policy diffusion and policy transfers. To my knowledge, few comparative studies seek to explain emerging social assistance institutions (Leisering 2019; Schmitt et al. 2015; Schmitt 2019; Dodlova et al. 2018; see Schmitt, Chap. 6, this volume). ${ }^{6}$

Quantitative studies are scarce, which is largely due to the paucity of reliable data. Díaz-Cayeros and Magaloni (2009) are interested in factors explaining the timing of the adoption of conditional income transfers in Latin America and the Caribbean. Relying on a survival model and on data for 21 countries in the region, they find that inequality, the level of development, state capacity and the durability of the political regime all contribute to earlier adoption, but economic growth is identified as a potentially delaying factor. Their key finding is that, after controlling for these factors, the ideology of the executive plays no significant role, suggesting that "the convergence we see when it comes to poverty-fighting strategies may have to do with dilemmas that all Latin American governments must face, whatever their own or their supporters' ideologies and policy preferences" (Díaz-Cayeros and Magaloni 2009, 47). By contrast,

\footnotetext{
${ }^{5}$ Single country studies on the expansion of social assistance contribute significantly to our understanding of the processes involved but are not reviewed here. In Latin America, single country studies focus on identifying preferences of social assistance programs and potential electoral implications. These studies rely on standard regression techniques, using attitudinal or experimental household survey data. More recently, Zucco has collected and analyzed experimental data (Zucco et al. 2019). In sub-Saharan Africa, two research programs on the politics of social protection (led by Jeremy Seekings at the University of Cape Town and by Sam Hickey and Tom Lavers at Manchester) have produced scores of single country studies (Hickey et al. 2020).

${ }^{6}$ Haggard and Kaufman (2008) and Huber and Stephens (2012) develop theoretical accounts of social policies and institutions in middle-income countries and Latin America, respectively, but do not focus on the recent growth of social assistance. Two studies provide information on the emergent institutions themselves in Latin America (Székely 2015; CEPAL 2015).
} 
Borges (2018) finds that left ideology has contributed to the diffusion of conditional income transfers in Latin America.

Borges Sugiyama (2011) discusses the spread of conditional income transfer programs in Latin America, applying a Cox event history model to data from Latin American countries, combined with a qualitative study of the role of transnational actors. The quantitative component finds that a variable capturing neighborhood effects is the only significant independent variable. The model finds no support for variables capturing "policy bargaining" explanations (needs, capacity and governing coalition ideology). The qualitative component finds that international organizations display multiple and overlapping effects on diffusion: "They help shape international norms and then reinforce them through funding arrangements" (Borges Sugiyama 2011, 264).

Brooks (2015) applies a logistic regression-weighted lag-dependent variable model to a cross-section sample of social assistance programs, with the objective of identifying correlates of conditional income transfer program adoption. Her findings are summarized as follows: "the recent shift toward cash transfers for the poorest citizens in the developing world has emerged through a deepening of democracy, macroeconomic conditions, and horizontal channels of communications across nations that enable governments to discern whether such design is a reasonable investment of financial and institutional resources for their country" (Brooks 2015, 575). Regarding the role of the World Bank (captured by a variable indicating the total bank funding flowing to the specific country), she finds no statistically significant correlation with conditional income transfer adoption but a significant correlation if all types of cash transfers are included. Brooks' findings are challenged by Simpson (2018) who relies on non-parametric measures of association and an updated crosssection sample of programs. If anything, this study demonstrates that findings are highly dependent on particular samples and analytical methods.

The absence of comprehensive comparative data on social assistance was a major challenge, but several new datasets now available should facilitate comparative research. They include the World Bank's ASPIRE database (World Bank 2016), the non-contributory social transfer program dataset NSTP (Dodlova et al. 2018), the Floor-Cash dataset 
(Weible et al. 2015) and Social Assistance in Low and Middle Income Countries (SALMIC) (Barrientos 2018).

Qualitative studies rely almost exclusively on expert interviews and documentation. The sample of countries is largely ad hoc, and expert interviews are heavily weighted toward transnational actors and agency officials. Process tracing and network analysis are sometimes employed, but counterfactuals are seldom discussed.

The findings from qualitative studies on Latin American conditional income transfers and those focusing on sub-Saharan Africa show some subtle differences. Fenwick (2013) examines Brazil and Argentina and finds that transnational actors played a secondary role with conditional income transfer adoption. As she puts it, "what matters most is what type of feedback effect intersects with transnational policy ideas" (Fenwick 2013, 162). Martínez Franzoni and Voorend (2011) compare the adoption of conditional income transfers in Chile, Costa Rica and El Salvador. They stress the role of the international epistemic community and the consensus on how best to deploy antipoverty programs; "[h] owever, differences in each program's design hint at cross-national differences and the role of domestic factors in adapting policy recommendations to national environments" (Martínez Franzoni and Voorend 2011, 285). Garay (2016) provides a detailed and comprehensive analysis of the growth of social assistance in four Latin American countries (Mexico, Argentina, Brazil and Chile). She finds no evidence in support of the view that transnational actors have played a significant role in the expansion of social assistance in these countries. In sum, qualitative studies on Latin America acknowledge transnational actors but discount their influence on the growth of social assistance.

Hickey and Seekings (2020) and Hickey et al. (2020) provide a perspective on the adoption and diffusion of social assistance in sub-Saharan Africa. Their research relies on qualitative methods, complemented by process tracing and the analysis of documentation. Hickey and Seekings (2020) focus specifically on the role of donors with the expansion of social assistance. Their approach to policy diffusion is in line with the global social policy perspective, including an emphasis on ideational factors. In their view, "the global SCT [Social Cash Transfer] agenda has been created by international organizations" (Hickey and Seekings 2020, 
17). Hickey et al. (2020) extend their analysis to including domestic policy factors in the adoption of social assistance. ${ }^{7}$ They find that transnational influences have been important in some countries, but not everywhere. Their process tracing analysis failed to "uncover evidence that these external agreements did more than legitimate-to some extent-the possibility of social protection" (Hickey et al. 2020, 11). They conclude that "whether or not national governments introduce or expand social assistance programmes depends primarily on politics within each country" (Hickey et al. 2020, 10).

The brief review of the comparative literature on the emergence of social assistance in low- and middle-income countries suggests the following points: (1) the bulk of available research focuses on policy adoption; (2) quantitative methods are scarce, perhaps due to the paucity of reliable data; (3) qualitative methods rely on key informant interviews and documentary analysis, sometimes complemented by process tracing; (4) apart from a subset of aid-dependent countries in sub-Saharan Africa, the literature does not find strong support for the view that the influence of multilaterals can explain the expansion of social assistance programs in low- and middle-income countries.

\section{Social Policy Adoption and Emerging Institutions}

A focus on transnationally driven social policy diffusion might not contribute significantly to our understanding of emerging institutions in low- and middle-income countries. Policy adoption and policy transfers emphasize short-term, perhaps fleeting, government decision-making. Instead, the study of institutions focuses attention on longer-term redistributive patterns and commitments embedded in norms and practices and consistent with economic, social and political conditions. In the con-

\footnotetext{
7 "Foreign donors operate as a distinct faction (or factions) within political settlements, whose power and influence do not simply flow from the importance of the resources they provide but, vitally, depend on the evolution of aid relations over years and the strategies African governments have devised to manage these donors" (Hickey et al. 2020, 7).
} 
text of the recent expansion of social assistance, a focus on policy adoption reflects the short-term focus of transnational actors and international assistance. A brief review of two past examples of transnationally driven social policy transfers-provident funds and individual retirement accounts — will help clarify this point.

Colonial administrators were central to the adoption of provident funds in several British colonies in the 1950s and 1960s. Provident funds are compulsory saving schemes in which workers and employers make payroll contributions to a fund attracting uniform rates of interest. Workers can withdraw their savings and interests accrued for specified purposes: retirement, medical expenses, education expenses and housing. Colonial administrators "pushed" provident funds as a scaled-down version of social insurance, in the belief that the colonies lacked the capacity to support the latter (McKinnon et al. 1997). Provident funds were also appropriate to conditions in which labor moved between colonial territories as it enabled savings portability (Parrott 1968).

Provident funds were first adopted in Asia (Indonesia and Malaysia in 1951, India in 1952, Singapore in 1953, Sri Lanka in 1958); the Middle East (Egypt in 1955, Iraq in 1956) and later Africa (Nigeria in 1961, Tanzania in 1964, Zambia, Ghana and Kenya in 1965, Uganda in 1967) and finally in the Caribbean and Pacific Islands in the early 1970s.

The adoption of provident funds matches a "canonical" model of transnationally driven policy diffusion and transfer. Yet, with few exceptions, provident fund diffusion sheds very little light on existing welfare institutions in the countries concerned. Most of the colonies replaced provident funds by social insurance soon after independence. In Africa, provident funds collapsed under spiraling debt and public deficits in the 1980s. Singapore and Malaysia represent a handful of examples of countries maintaining provident funds as their core welfare institution.

Pension reform in 12 countries in Latin America in the 1990s led to the replacement of defined benefit pay-as-you-go pension schemes with individual retirement accounts (Mesa-Lago 2007). Later, pension reform spread to ten countries in Central and Eastern Europe. Policy transfers associated with individual retirement accounts have been studied closely (Orenstein 2011; Weyland 2008). Strong support and advocacy from the 
World Bank appeared to provide another "canonical" case of transnationally driven policy diffusion (Béland and Orenstein 2013).

In Latin America, individual retirement accounts remain in place in only nine countries. They are largely residual institutions in terms of the share of contributors in the labor force, except for Chile and Costa Rica (Kritzer et al. 2011). In Central and Eastern Europe, individual retirement accounts introduced in the late 1990s and 2000s differed in important respects from the Latin American reforms, as they did not replace public pension systems but served as a complementary second pillar. The 2007 global financial crisis led to pension reform reversals (Whitehouse 2012). Hungary renationalized individual retirement accounts, and parametric reforms in most of the other countries have rebalanced public and private pension system components, strengthening the former.

These examples show that a focus on transnationally driven social policy adoption, whilst valuable in their own domain, might not take us very far with developing theories capable of explaining the shape of emerging welfare institutions in low- and middle-income countries.

\section{Conceptualizing Transnational Actors}

Theories seeking to explain the development of welfare institutions in long-standing industrialized countries have focused attention on underlying economic and political conditions. Welfare institutions are studied as the outcome of processes of social stratification and coalition politics (Castles et al. 2012). For example, the influential work by EspingAndersen and the power resources school (Esping-Andersen 1990, 1999; Korpi 1980) distinguished three main types of welfare regimes: a social democratic regime in the Nordic countries, a conservative regime in Central Europe and a liberal regime in the Anglo-Saxon countries. The distinctiveness of these welfare regimes is explained as the outcome of alternative class coalitions between workers and the middle class, leading to distinct institutional patterns. The nature of participation of the middle classes in redistributive coalitions emerges as key to the distinctive pattern of welfare states (van Kersbergen and Vis 2014). Theories of the development of welfare institutions in long-standing industrialized coun- 
tries did not pay significant attention to external factors, but more recent research on welfare state retrenchment takes account of globalization and regional integration (Manow 2001).

\section{Integrating Transnational Actors}

Theories of emerging institutions in low- and middle-income countries will need to address the specific forms of stratification and coalition politics present in low- and middle-income countries. In addition, they will need to pay particular attention to cross-national interdependencies and transnational actors. This section focuses on the latter.

The Introduction advanced the view that comparative literature on the expansion of social assistance has overstated the role of transnational actors, particularly multilaterals (see Chinyoka and Ulriksen, Chap. 10, this volume). The discussion in earlier sections argued that this bias has implications for the formulation of core research questions and for the effectiveness of qualitative methods. Uncritical assessments of the influence of transnational actors in the expansion of social assistance are reinforced by deficits in the conceptualization of the role of transnational actors in social policy. Theories of welfare institutions in long-standing industrialized countries have taken great care to conceptualize the role of key actors: trade unions, left parties, middle classes and employers. Yet transnational actors, especially multilaterals, are seldom the subject of serious scrutiny in discussions on welfare institutions and social policy in low- and middle-income countries. In literature, transnational actors appear either as binary variables in quantitative studies or as exogenous agents or stakeholders in qualitative studies. Which interests do they represent? What is the source of their power or influence? What is their ideology? Are they an economic class? These prior methodological questions, helping to conceptualize transnational actors, are seldom considered systematically. This section discusses two alternative perspectives.

A good starting point is Meyer's (2010) distinction between phenomenological approaches on the one hand and realist approaches on the other. Realist approaches explain welfare institutions in terms of power and interests. Policy models are "constructed to their advantage by pow- 
erful and interested actors" (Meyer 2010, 11). Instead, phenomenological approaches emphasize the role of cultural processes of the dissemination of world norms and values, in the context of which actors implement highly standardized and scripted narratives. We will return to realist accounts below, but it will be helpful to review how Meyers's world society perspective would explain the role and influence of transnational actors.

\section{Phenomenological Accounts of Transnational Actors}

In Meyer's world society, national and supranational bureaucracies and policy networks disseminate, design and implement world norms. These norms "are universalistic, but also provide a universal orderly control system" (Meyer 2010, 11). In this phenomenological perspective, "institutionalised systems construct the actors as well as their activities" $(2010,2)$ where "the actor on the social stage is a scripted identity and enacts scripted action ... [whilst] the institutional system-the organizations and cultural meanings that write and rewrite the scripts-become central" (Meyer 2010, 11). ${ }^{8}$ The primacy of universalistic norms entails that models "of the modern actor stress cooperation in a global or universal order and good global citizenship" (Meyer 2010, 11).

Meyer explains the growth of professional and organizational structures as a means of combining constructed universalistic actor scripts by a context in which "no state-like authority can arise to organize perceived interdependencies and moderate conflict ... And their social authority derives from their disinterested reflection of transcending purposes, not from their own interests" (Meyer 2010, 6). Professional and expert individuals and their bodies are "disinterested Others". "They represent such collective and putatively universal goods as the environment, generalized human rights, or principle of rationality and progress" (Meyer 2010, 7).

The disjunction between these universalistic models and actual practice reinforces supranational interventions. "Everywhere there are injus-

\footnotetext{
${ }^{8}$ Although not directly relevant for the focus of this chapter, Usui (1994) tests the word society perspective by way of using data on social security legislation and attendance to ILO Conferences. The findings "suggest that the world institutional environment is a strong force in the universalisation of social welfare policies" (Usui 1994, 271).
} 
tices and inconsistencies made visible through forms of scrutiny including scientific measurement and investigation. The injustices in a stateless world, call for further expansion in the imagined capacities and responsibilities of human and organizational actors" (Meyer 2010, 13).

This perspective is reflected in the global social assistance models developed in von Gliszczynski and Leisering (2016) and Leisering (2019). They understand global social policy models as models originating from, and associated with, international organizations. Their legitimacy rests on their claim to represent universal world cultural values and ideas rather than vested interests, they are "disinterested others". According to Meyer, they focus on "cognitive and normative models of SCT devised by international organisations rather than actual social cash transfer programmes" (von Gliszczynski and Leisering 2016, 326). They find that "in the 2000s international organizations established a new field of global social policy, SCT, defined by way of four models_-social pensions, family allowances, conditional cash transfers and general household assistance" (von Gliszczynski and Leisering 2016, 337).

Global social policy also assigns a central role to transnational actors in the formation of social policy in low- and middle-income countries (Deacon 1997). While acknowledging the influence of domestic factors on social policy, its core aim is to "restate the importance of a focus on the specific social policy recommendations which certain global players make to countries concerning their national social policies" (Deacon and Stubbs 2013, 6). Its main focus is "on the one hand, the ideas, discourses and programmes of social policy developed by international (multilateral) organizations, and on the other hand the influence of transnational policy actors on domestic policy change" (Yeates 2018, 28). The justification of this central focus on transnational actors rests on the view that they "shape policy agendas globally, and can change the course of institutional pathways by exercising coercive and persuasive resources that initiate and progress policy initiatives" (Yeates 2018, 29).

Global social policy shares with world society a globalist approach, but it places a stronger emphasis on the agency of transnational policy actors, whereas they are simply scripted others in world society. Global social policy and world society also emphasize a primary role for discourse in 
the construction of policy models (Tag 2013). ${ }^{9}$ This connects directly to a series of recent papers discussing ideational dimensions of social policy (Béland 2016; Béland and Orenstein 2013; Jenson 2010). Ideational accounts of social policy reforms are well in line with the emphasis on discourse in world society and global social policy perspectives. Ideational processes "help construct the social and economic problems most public policies are designed to address... [and] help actors define their interests, which are shaped not only by material conditions but through interpretations of these conditions" (Béland and Orenstein 2013, 127). The main premise justifying the interest in ideational processes in social policy reform is that they influence domestic policy, especially ideational processes among multilaterals. ${ }^{10}$ Ideas matter because they result in policy change.

Applying ideational perspectives to international organizations, Béland and Orenstein (2013) provide an interesting characterization. First, international organizations are "open systems" in the sense that they interact freely with their environment, without the restrictions of a worldview or core interests and preferences. ${ }^{11}$ Second, international organizations have a measure of autonomy with respect to the countries they serve. Third, their lack of "hard" power gives a prominent role to ideational processes in defining their influence on domestic policy. ${ }^{12}$ This characterization of the "power" of international organizations is a close relative of the "disinterested Other" in Meyer's world society, however with an added emphasis on the role of contestation and learning in global social policy.

\footnotetext{
${ }^{9}$ Deacon and Stubbs refer to discourse as the "most slippery of concepts". They define it as "the inter-subjective production of meaning" and as "order of ideas and practices which frame the context within which specific policy debates are situated” (Deacon and Stubbs 2013, 15).

10 "Examining changing ideational and discursive processes within international organizations matters because studies have shown that these processes can have a direct influence on domestic policy. This makes the analysis of how ideas and discourse evolve within international organizations one of the most important frontiers of global policy theory" (Béland and Orenstein 2013, 127).

11 "In contrast to advocacy think tanks, which identify with relatively stable ideological creeds and policy paradigms, international organizations can and do change" (Béland and Orenstein 2013, 137).

${ }^{12}$ Taking on board international organizations' "lack of veto power ... and the limits of financial conditionalities, ideational processes are the most central means through which they attempt to shape domestic policy" (Béland and Orenstein 2013, 127).
} 
This characterization resonates with the international organizations' own reflective view of their place in the world—one they miss few opportunities to project.

\section{Realist Accounts of Transnational Actors and Influence}

Realist accounts of transnational actors and influences in social policy in low- and middle-income countries depart from the basic proposition that social policy reflects the "distribution of preferences and their political organizations" in their respective polities (Haggard and Kaufman 2008, 359). External factors are important because they influence the political and economic conditioning of domestic preferences, and in some cases directly through exercising power over jurisdictions (e.g. structural adjustment in Latin America, the Soviet Bloc). ${ }^{13}$ Transnational influences are one of the factors capable of influencing domestic social policy.

What explains the particular preferences and interests of transnational actors? In realist perspectives, international organizations are primarily theorized as reflecting the preferences of hegemonic countries or groups of countries. When discussing pension reform in Latin America, for example, Huber and Stephens (2012) underline the crucial role of international financial institutions (IFIs). The spread of pension is explained by the fact that "neoliberal ideology penetrated the policy-making circles in many Latin American and (European) countries ... There is clearly a material basis to the hegemony of neoliberalism in the form of control by advanced countries of the IFIs" (Huber and Stephens 2012, 252). This is disputed by Haggard and Kaufman (2008) in their study on social policy reforms in middle-income countries in Latin America, East Asia and Eastern Europe. They argue that the hegemonic influence of the USA has largely subsided compared to the earlier Cold War period. While acknowledging that social policy shows some convergence in a neoliberal direction,

\footnotetext{
13 "There is a plethora of ways in which 'the international' operates on states: war and security calculations; cleavages over economic openness; the influence of international organizations; and the diffusion of policy ideas" (Haggard and Kaufman 2008, 348).
} 
they see "very little evidence that international political forces ... are leading to a homogenization of social policy" (Haggard and Kaufman 2008, 350).

Some studies on the influence of international organizations on the recent expansion of social assistance in low- and middle-income countries echo Huber and Stephens' description of the dominance of neoliberalism in pension reform. Teichman (2007), for example, finds a consistent thread from neoliberal ideas to the IFIs' endorsement of conditional income transfers. Conditional income transfers, and more generally tax-financed social assistance, are assessed as being consistent with a residual view of social and public policy present in neoliberalism.

Discussing social policy in Latin America, Huber and Stephens (2012) find a shift in the position of international organizations as regards social spending. They suggest "the IFIs, particularly the World Bank, have abandoned their Washington Consensus position and now advocate investments in human capital and reductions in poverty and inequality" (Huber and Stephens 2012, 261). Arguably, this is consistent with the IFIs' advocacy of safety nets and especially conditional income transfers. ${ }^{14}$

In the context of a realist perspective on the role of transnational actors in the expansion of social assistance in low- and middle-income countries, a key question is whether the IFIs' potential shift in preferences reflects a shift in the domestic preferences of long-standing industrialized countries or a shift in the latter's preferences regarding social policy in low- and middle-income countries. The former follows from proposals for reforming welfare states in a social investment direction (Hemerijck 2013). The latter would be consistent with long-standing industrialized countries' concerns with conflict (e.g. "fragile" states) or transnational migration. A shift in the preferences of transnational actors for social policy in low- and middle-income countries might also be explained by potential contestation among international organizations, perhaps reflecting differences across long-standing industrialized countries, leading to a

\footnotetext{
${ }^{14}$ I say arguably because it is not clear that, in the context of social policy, the World Bank has a preference for investment in human development (conditional cash transfers). If anything, the safety net operational work of the Bank is a mixed bag.
} 
paradigm shift. ${ }^{15}$ An alternative reading is that the change in the social policy preferences of international organizations reflects changes in domestic social policy among emerging economies. ${ }^{16} \mathrm{It}$ is worth restating the fact that the World Bank built on experiences about conditional cash transfers made in Brazil, Mexico and Bangladesh.

\section{Transnational Actors and Social Assistance Expansion}

This brief review was meant to shed light on alternative conceptualizations of the role of transnational actors in domestic policy. Can they help us understand the recent expansion of social assistance in low- and middle-income countries?

World society phenomenological accounts would suggest, as von Gliszczynski and Leisering (2016) do, that transnational actors are best conceptualized as "disinterested Others" devising and implementing a universalistic script. The evolution of global social policy suggests a certain degree of convergence with world society. Earlier versions of global social policy (Deacon 1997) show multiple references to the hegemony of the Washington Consensus advanced by realist perspectives, but growing reliance on ideational approaches in later versions (Deacon and Stubbs 2013) moves it closer toward the universalistic script in world society (Tag 2013).

The findings from the review of comparative studies in section "Comparative Research on Social Assistance" and the broader literature on the growth of social assistance challenge phenomenological perspectives in important ways. The multiplicity of scripts (e.g. policy instruments), the indeterminacy of transnational advice and influence (e.g. contrasting assessment of conditional income transfers) and the lack of

\footnotetext{
${ }^{15}$ See Jenson (2010) for a comparison of the diffusion of social investment policies in the OECD and Latin America, the latter emphasizing the growth of conditional income transfers. Pritchett (2002) provides a perspective on the role of contestation within the World Bank to explain the incidence of impact evaluations and, generally, evidence gathering.

${ }^{16}$ Researchers have suggested that conditional income transfers could in principle appeal to both neoliberal and progressively oriented policy-makers (González de la Rocha and Escobar 2012; Brooks 2015). In fact, conditional income transfers have been supported by left-of-center and right-of-center coalitions in Latin America.
} 
evidence concerning the very influence of multilaterals_-all work to challenge phenomenological accounts. This is significant because phenomenological perspectives provide, albeit implicitly, much of the grounding for ideational studies on social assistance diffusion in low- and middleincome countries.

Realist perspectives on the influence of transnational actors conceptualize international organizations in terms of the preferences and power of hegemonic early industrializers. ${ }^{17}$ The influence of transnational actors on domestic policy flows from the global power of long-standing industrialized countries. Realist accounts have interpreted the growth of social assistance as an extension of neoliberal policies pushed by hegemonic long-standing industrialized countries. Again, comparing this perspective with the main findings from the review of comparative studies in section "Comparative Research on Social Assistance" suggests that they are significant. Chief among them is the fact that conditional income transfers did not emerge from the prescriptions of IFIs in indebted or aid-dependent countries, but instead they emerged from domestic policy innovations in Brazil and Mexico.

An alternative realist approach is to suggest that there has been a shift in the preferences of hegemonic actors toward social investment, consistent with the view put forward by Huber and Stephens (2012). It is perhaps too early to assess this hypothesis. There is growing interest and discussion around social investment in European countries (Hemerijck 2013) but, aside from long-standing social policy in the Nordic countries, it would be difficult to describe these developments as a paradigm shift at this point in time. Social investment is hardly a priority in the USA.

Perhaps the main conclusion that can be drawn from this section is that further research is needed to construct a persuasive account of the

\footnotetext{
${ }^{17}$ From a realist perspective, the view of multilaterals as "ideas brokers" does not take us very far with theorizing their role. Whatever explanatory power multilaterals could offer in theorizing emerging welfare institutions in low- and middle-income countries could be captured more directly by the core interests and preferences they intermediate. This would also apply to contestation among transnational actors. Contestation reflecting the preferences of grouping (factions) among long-standing industrialized countries in the context of social assistance in Africa is discussed in Hickey et al. (2020).
} 
role of transnational actors in the expansion of social assistance in lowand middle-income countries (see Shriwise, Chap. 2, this volume).

\section{Conclusions}

The rapid growth of social assistance in low- and middle-income countries has highlighted the need to develop theories capable of explaining emergent welfare institutions in these countries. Comparative research is essential to this project. It is urgent to identify with precision the forms of stratification explaining the shape of emerging institutions. It is also important to pay attention to interdependencies, especially as these are likely to have stronger influence on the shape of the emerging welfare institutions in low- and middle-income countries than they did in the expansion of welfare states in long-standing industrialized countries.

To date, the scarce comparative literature has paid considerable attention to the role of transnational actors. Prominent studies attribute the expansion of social assistance, conditional income transfers in particular, to the influence of transnational actors, especially multilaterals. This contribution has challenged this widely held view. Transnational actors are highly visible in international policy debates and in some cases in domestic debates in low- and middle-income countries, especially in aiddependent countries. However, the view that the expansion of social assistance is explained by the influence of multilaterals finds limited support in the literature reviewed in this contribution.

It is important to address this issue because it carries implications for the focus, scope and methods of comparative research. A disproportionate focus on transnational actors biases comparative research in ways that might turn out to be counterproductive. Its implicit research questionwhat makes policies travel? - crowds out more fundamental questions about the causal factors giving shape to emerging welfare institutions in low- and middle-income countries (Schmitt et al., Chap. 14, this volume). A brief review of two "canonical" transnationally driven social policy reforms, provident funds and individual retirement accounts, has demonstrated the need to look beyond short-term transnationally driven 
policy diffusion processes in order to explain the shape of medium- and longer-term institutions in low- and middle-income countries.

The discussion in the contribution has questioned the, at best partial, conceptualization of transnational actors in the comparative literature. Transnational actors often appear as binary variables in quantitative research or as exogenous actors in qualitative studies. The contribution has sketched alternative phenomenological and realist perspectives on transnational actors and assessed their potential contribution to understanding the role of transnational actors in the emergence of welfare institutions in low- and middle-income countries. Further research is needed to refine these perspectives before they can shed light on the role of transnational actors in shaping emergent welfare institutions.

The way forward for comparative research on emerging welfare institutions in low- and middle-income countries involves more of the following: study of institutions, study of domestic factors in the context of political and economic interdependencies, quantitative comparative analysis, attention to counterfactuals and better data.

\section{References}

Barrientos, Armando. 2013. Social Assistance in Developing Countries. Cambridge: Cambridge University Press.

2018. Social Assistance in Low and Middle Income Countries Dataset

(SALMIC). Manchester: Global Development Institute, University of Manchester. www.social-assistance.manchester.ac.uk.

Béland, Daniel. 2016. Ideas and Institutions in Social Policy Research. Social Policy and Administration 50 (6): 734-730.

Béland, Daniel, and Mitchell A. Orenstein. 2013. International Organizations as Policy Actors: An Ideational Approach. Global Social Policy 13 (2): 125-143. Borges, Fabián A. 2018. Neoliberalism with a Human Face. Comparative Politics 50 (2): 147-167.

Borges Sugiyama, Natasha. 2011. The Diffusion of Conditional Cash Transfer Programs in the Americas. Global Social Policy 11 (2-3): 250-278.

Brooks, Sarah. 2015. Social Protection for the Poorest: The Adoption of Antipoverty Cash Transfer Programs in the Global South. Politics and Society 43 (4): 551-582. 
Castles, Francis G., Jane Lewis Stephan Leibfried, Herbert Obinger, and Christopher Pierson. 2012. The Oxford Handbook of the Welfare State. Oxford: Oxford University Press.

CEPAL. 2015. Desarrollo Social Inclusivo. Una Nueva Generación de Politicas Para Superar La Pobreza y Reducir La Desigualdad En América Latina y El Caribe. Report LC.L/4056 (CDS.1/3). Santiago, Chile: CEPAL, División Desarrollo Social.

Deacon, Bob. 1997. Global Social Policy. International Organizations and the Future of Welfare. London: Sage.

Deacon, Bob, and Paul Stubbs. 2013. Global Social Policy Studies: Conceptual and Analytical Reflections. Global Social Policy 13 (1): 5-23.

Díaz-Cayeros, Alberto, and Beatriz Magaloni. 2009. Aiding Latin America’s Poor. Journal of Democracy 20 (4): 36-49.

Dodlova, Marina, Anna Giolbas, and Jann Lay. 2018. Non-Contributory Social Transfer Programmes in Developing Countries: A New Dataset and Research Agenda. Data in Brief 16: 51-64.

Esping-Andersen, Gosta. 1990. The Three Worlds of Welfare Capitalism. Cambridge: Polity Press.

- 1999. Social Foundations of Postindustrial Economies. Oxford: Oxford University Press.

Fenwick, Tracy Beck. 2013. Stuck Between the Past and the Future: Conditional Cash Transfer Programme Development and Policy Feedbacks in Brazil and Argentina. Global Social Policy 13 (2): 144-167.

Garay, Candelaria. 2016. Social Policy Expansion in Latin America. New York: Cambridge University Press.

von Gliszczynski, Moritz, and Lutz Leisering. 2016. Constructing New Global Models of Social Security: How International Organizations Defined the Field of Social Cash Transfers in the 2000s. Journal of Social Policy 45 (2): 325-343.

González de la Rocha, Mercedes, and Agustín Lapatí Escobar. 2012. Pobreza, Transferencias Condicionadas y Sociedad. Mexico City: CIESAS.

Haggard, Stephan, and Robert R. Kaufman. 2008. Development, Democracy and Welfare States. Latin America, Asia and Eastern Europe. Princeton: Princeton University Press.

Hemerijck, Anton. 2013. Changing Welfare States. Oxford: Oxford University Press.

Hickey, Sam, and Jeremy Seekings. 2020. Who Should Get What, How and Why? DfID and the Transnational Politics of Social Protection. In The Politics 
of Social Protection in Eastern and Southern Africa, ed. Sam Hickey, Tom Lavers, Miguel Niño-Zarazúa, and Jeremy Seekings, 249-276. Oxford: Oxford University Press.

Hickey, Sam, Tom Lavers, Miguel Niño-Zarazúa, and Jeremy Seekings. 2020. The Negotiated Politics of Social Protection in Sub-Saharan Africa. In The Politics of Social Protection in Eastern and Southern Africa, ed. Sam Hickey, Tom Lavers, Miguel Niño-Zarazúa, and Jeremy Seekings, 249-276. Oxford: Oxford University Press.

Huber, Evelyne, and John D. Stephens. 2012. Democracy and the Left in Latin America. Social Policy and Inequality in Latin America. Chicago: University of Chicago Press.

Jenson, Jane. 2010. Diffusing Ideas for After Neoliberalism: The Social Investment Perspective in Europe and Latin America. Global Social Policy 10 (1): 59-84.

van Kersbergen, Kees, and Barbara Vis. 2014. Comparative Welfare State Politics:

Development, Opportunities, and Reform. Cambridge: Cambridge University Press.

Korpi, Walter. 1980. Social Policy and the Distributional Conflict in the Capitalist Democracies: A Preliminary Comparative Framework. West European Politics 3: 296-316.

Kritzer, Barbara E., Stephen J. Kay, and Tapen Sinha. 2011. Next Generation of Individual Account Pension Reforms in Latin America. Social Security Bulletin 71 (1): 35-76.

Leisering, Lutz. 2019. The Global Rise of Social Cash Transfers. How States and International Organizations Constructed a New Instrument for Combating Poverty. Oxford: Oxford University Press.

Manow, Philip. 2001. Comparative Institutional Advantages of Welfare State Regimes and New Coalitions in Welfare State Reforms. In The New Politics of the Welfare State, ed. Paul Pierson. Oxford: Oxford University Press.

Martínez Franzoni, Juliana, and Koen Voorend. 2011. Actors and Ideas Behind CCTs in Chile, Costa Rica and El Salvador. Global Social Policy 11 (2-3): 279-298.

McKinnon, Roddy, Roger Charlton, and Harry T. Munro. 1997. The National Provident Fund Model: An Analytical and Evaluative Reassessment. International Social Security Review 50 (2): 43-61.

Mesa-Lago, Carmelo. 2007. Reassembling Social Security. A Survey of Pensions and Healthcare Reforms in Latin America. Oxford: Oxford University Press. Meyer, John W. 2010. World Society, Institutional Theories, and the Actor. Annual Review of Sociology 36: 1-20. 
Obinger, Herbert, Carina Schmitt, and Peter Starke. 2013. Policy Diffusion and Policy Transfer in Comparative Welfare State Research. Social Policy and Administration 47 (1): 111-129.

Orenstein, Mitchell A. 2011. Pension Privatization in Crisis: Death or Rebirth of a Global Policy Trend? International Social Security Review 64 (3): 65-80. Parrott, A.L. 1968. Problems Arising from the Transition from Provident Funds to Pension Schemes. International Social Security Review 21 (4): 530-557.

Peck, Jamie, and Nick Theodore. 2015. Fast Policy. Experimental Statecraft at the Thresholds of Neoliberalism. Minneapolis: University of Minnesota Press.

Pritchett, Lant. 2002. It Pays to Be Ignorant: A Simple Political Economy of Rigorous Program Evaluation. The Journal of Policy Reform 5 (4): 251-269.

Schmitt, Carina. 2019. The Coverage of Social Protection in the Global South. International Journal of Social Welfare. Online first.

Schmitt, Carina, Hanna Lierse, Herbert Obinger, and Laura Seelkopf. 2015. The Global Emergence of Social Protection: Explaining Social Security Legislation. Politics and Society 43 (4): 503-524.

Simpson, Joshua. 2018. Do Donors Matter? An Analysis of Conditional Cash Transfer Adoption in Sub-Saharan Africa. Global Social Policy 18 (2): 143-168. Székely, Miguel. 2015. Cambios En La Institucionalidad de La Politica de Protección Social En América Latina y El Caribe: Avances y Nuevos Desafios. Nota Técnica 810, Washington, DC: Inter-American Development Bank.

Tag, Miriam. 2013. The Cultural Construction of Global Social Policy: Theorizing Formations and Transformations. Global Social Policy 13 (1): $24-44$.

Teichman, Judith. 2007. Redistributive Conflict and Social Policy in Latin America. World Development 36 (3): 446-460.

Usui, Chikako. 1994. Welfare State Development in a World System Context:

Event History Analysis of First Social Insurance Legislation among 60 Countries, 1880-1960. In The Comparative Political Economy of the Welfare State, ed. Thomas Janoski and Alexander M. Hicks, 254-277. Cambridge: Cambridge University Press.

Weible, Karen, Tobias Böger, John Berten, Moritz von Gliszczynski, and Lutz Leisering. 2015. FLOORCASH. Bielefeld: Bielefeld University. www. floorcash.org.

Weyland, Kurt. 2008. Bounded Rationality and Policy Diffusion. Social Sector Reform in Latin America. Princeton: Princeton University Press.

Whitehouse, Edward. 2012. Reversals of Systemic Pension Reforms in Central and Eastern Europe, OECD Pensions Outlook. Paris: OECE Social Policy Division. 
World Bank. 2015. The State of Social Safety Nets 2015: Report. Washington, DC: The World Bank. 2016. Atlas of Social Protection - Indicators of Resilience and Equity. Database ASPIRE. http://datatopics.worldbank.org/aspire/home.

Yeates, Nicola. 2018. Global Approaches to Social Policy, 2018-2. UNRISD Working Paper, Geneva: UNRISD.

Zucco, Cesar, Juan Pablo Luna, and Gokce Ozgen Baykal. 2019. Do Conditionalities Increase Support for Government Transfers? Journal of Development Studies, online.

Open Access This chapter is licensed under the terms of the Creative Commons Attribution 4.0 International License (http://creativecommons.org/licenses/ by/4.0/), which permits use, sharing, adaptation, distribution and reproduction in any medium or format, as long as you give appropriate credit to the original author(s) and the source, provide a link to the Creative Commons licence and indicate if changes were made.

The images or other third party material in this chapter are included in the chapter's Creative Commons licence, unless indicated otherwise in a credit line to the material. If material is not included in the chapter's Creative Commons licence and your intended use is not permitted by statutory regulation or exceeds the permitted use, you will need to obtain permission directly from the copyright holder.



